\title{
Use of mathematical models in the study of bodily growth in GIFT strain Nile tilapia ${ }^{1}$
}

\author{
Utilização de modelos matemáticos no estudo do crescimento corporal de tilápia \\ nilótica da linhagem GIFT
}

\author{
Alda Lúcia de Lima Amancio ${ }^{2 *}$, José Humberto Vilar da Silva², João Batista Kochenborger Fernandes ${ }^{3}$, Nilva \\ Kazue Sakomura ${ }^{3}$ e George Rodrigo Beltrão da Cruz $^{2}$
}

\begin{abstract}
The objective of this study was to evaluate the accuracy of five mathematical models (Gompertz, Logistic, Linear Hyperbolic, Quadratic and Quadratic Logarithmic) to describe the growth curve of GIFT strain Nile tilapia, Oreochromis niloticus, and to characterize the growth trajectory of body parts. To do this, 1,000 fingerlings, with an initial

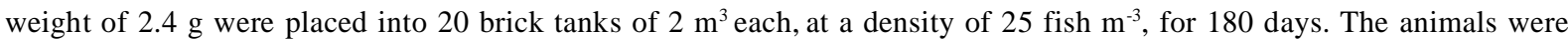
fed daily, using the protein levels and number of meals appropriate to each stage. Every two weeks 20 fish were randomly sampled, submitted to a fasting period of $48 \mathrm{~h}$ and then slaughtered by thermal shock, in order to determine the weight of the whole fish, the skin without scales, skinless fillets, heart, liver, gills and gastrointestinal tract. The Gompertz and Logistic models presented the best fit to the growth curve for live weight, fillet and skin, however the Logistic model underestimated the asymptotic weights. Therefore, to describe the growth curve in GIFT strain Nile tilapia, the Gompertz model is suggested. According to the parameters estimated by the Gompertz model, Nile tilapia reach the age for maximum growth of the fillet and skin before that of body weight. Among the organs studied, growth of the gastrointestinal tract and gills takes place earlier than that of the heart and liver.
\end{abstract}

Key words: Oreochromis niloticus. Growth curve. Gompertz. Growth rate.

RESUMO - Objetivou-se com o presente estudo avaliar a acurácia de cinco modelos matemáticos (Gompertz, Logístico, Linear Hiperbólico, Quadrático e Quadrático Logarítmico) para descrever a curva de crescimento de tilápia nilótica Oreochromis niloticus da linhagem GIFT e, realizar a caracterização da trajetória do crescimento das partes corporais. Para tal, 1.000 alevinos com peso inicial de 2,4 g foram estocados em 20 tanques de alvenaria de $2 \mathrm{~m}^{3}$ numa densidade de 25 peixes $\mathrm{m}^{-3}$, por um período de 180 dias. Os animais foram alimentados diariamente, utilizando níveis de proteína e número de refeições diárias de acordo com cada fase. Quinzenalmente, foram amostrados aleatoriamente 20 peixes, submetidos a um jejum de $48 \mathrm{~h}$ e abatidos por choque térmico, para determinação dos pesos do peixe inteiro, peles sem escamas, filés sem pele, coração, fígado, brânquias e trato gastrointestinal. Os modelos Gompertz e Logístico foram os que mais se adequaram ao ajuste da curva de crescimento do peso vivo, do filé e da pele, todavia, o Logístico subestimou os pesos assintóticos. Desta forma, sugere-se o Gompertz para descrever a curva de crescimento de tilápia nilótica da linhagem GIFT. De acordo com os parâmetros estimados pelo modelo Gompertz, a tilápia nilótica atinge a idade de máximo crescimento do filé e pele antes da idade do peso vivo. Dentre os órgãos estudados, o crescimento do trato gastrointestinal e brânquias é mais precoce do que o do coração e fígado.

Palavras-chave: Oreochromis niloticus. Curva de crescimento. Gompertz. Taxa de crescimento.

\footnotetext{
*Autor para correspondência

Recebido para publicação em 26/04/2013; aprovado em 03/12/2013

Pesquisa realizada como parte da Tese de Doutorado da primeira autora, apresentada ao Programa de Doutorado Integrado em Zootecnia/ UFPB/UFRPE/UFC

${ }^{2}$ Departamento de Agropecuária, Colégio Agrícola Vidal de Negreiros, Centro de Ciências Humanas, Sociais e Agrárias, Universidade Federal da Paraíba, Bananeiras-PB, Brasil, 58.220-000, alda.amancio@yahoo.com.br,jvilar@cchsa.ufpb.br, georgebeltrao@hotmail.com

${ }^{3}$ Faculdade de Ciências Agrárias e Veterinárias, Universidade Estadual Paulista "Julio de Mesquita Filho", Via de Acesso Prof. Paulo Donato Castellane s/n, Jaboticabal-SP, Brasil, 14.884-900,jbatista@ caunesp.unesp.br, sakomura@fcav.unesp.br
} 


\section{INTRODUCTION}

The Nile tilapia, Oreochromis niloticus, was chosen to be used in breeding programs because of its rapid development, reproductive precocity and being widespread in many countries as a result of such zootechnical characteristics as hardiness, high resistance to disease and ease of adaptation in production systems (GUPTA; ACOSTA, 2004).

The GIFT (Genetically Improved Farmed Tilapia) strain of Nile tilapia that was introduced into Brazil in 2005 is the result of one of the most important breeding programs using $O$. niloticus conducted by the International Centre for Living Aquatic Resources Management (ICLARM), currently the WorldFish Center in the Philippines since 1988. Breeding was carried out by crossing eight strains: four wild populations of $O$. Niloticus, captured in Africa (Egypt, Ghana, Kenya and Senegal) and four domesticated populations from Asia (Israel, Singapore, Taiwan and Thailand). The strains were selected by comparing their performance and survival for 10 generations, from 1988 to 1997 (GUPTA; ACOSTA, 2004).

With the emergence of different strains of a species of zootechnical interest, it becomes necessary to study the growth curve of these animals under different environments and breeding methods (SANTOS et al., 2007). The use of mathematical functions to describe animal growth allows information to be summed up in a few strategic points of weight gain, and to describe weight development as a function of the age of the animal (THOLON; QUEIROZ, 2009). According to Gous et al. (1999), fitting a suitable model to the growth curve of the animals is the first step in predicting nutritional requirements for different genotypes. Several nonlinear mathematical models are used to describe the growth and deposition of body nutrients in animals. The models that stand out being Logistic, Brody, von Bertalanffy and Gompertz (MARCATO, 2007).

Linear mathematical models, such as Quadratic, Linear Hyperbolic and Quadratic Logarithmic (DAVE, 1971; BIANCHINI SOBRINHO, 1984), are also used to estimate growth curves.

Given the above, the aim of the present study was to assess the accuracy of different mathematical models in describing the growth curve of GIFT strain Nile tilapia, O. Oreochromis.

\section{MATERIAL AND METHODS}

The experiment lasted 180 days and was conducted at the Ornamental Fish Laboratory of the
Centre for Aquaculture at the Julio de Mesquita Filho São Paulo State University, located in Jaboticabal, in the

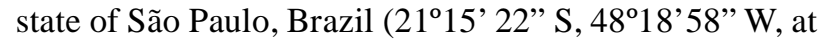
an altitude of $626 \mathrm{~m}$ ).

Fingerlings of GIFT strain Nile tilapia O. Niloticus, with an initial weight of approximately $2.4 \mathrm{~g}$, were placed into 20 brick tanks, each of $2 \mathrm{~m}^{3}$, which were installed in a greenhouse, at an initial density of 25 animals $\mathrm{m}^{-3}$, giving a total of 1,000 fish.

Initially, a commercial extruded feed (Table 1), of $45 \%$ crude protein (CP) in pellets of $1.5 \mathrm{~mm}$, was given six times a day until the animals reached a weight of about $5 \mathrm{~g}$. Then extruded food of $40 \% \mathrm{CP}(2.5 \mathrm{~mm})$ was given four times a day until their weight reached 20 to $30 \mathrm{~g}$. Subsequently, the fish were hand fed three times a day with a diet of $35 \% \mathrm{CP}(4 \mathrm{~mm})$ until attaining $200 \mathrm{~g}$, when this was changed for an extruded feed of $32 \% \mathrm{CP}$ (4-6 mm) until the fish got up to $400 \mathrm{~g}$. Finally, the animals started to receive extruded food of $28 \% \mathrm{CP}$ $(8-10 \mathrm{~mm})$ twice a day until the end of the experiment.

A continuous flow of water was maintained in the tanks, with the water being heated by heat exchanger. Weekly, in the morning, limnological parameters were analysed and the dissolved oxygen, $\mathrm{pH}$ and electrical conductivity were determined in situ with the aid of a digital oximeter (YSI 55), pH meter (YSI 100) and conductivity meter (YSI EC 300) respectively. At the same time, water samples were collected in order for the total alkalinity, ammonia and nitrite to be determined according to Golterman, Clymo and Ohnstad (1978). The water temperature was monitored daily each morning and afternoon with the aid of a thermometer.

Every two weeks, 20 fish were randomly sampled, with one fish being removed from each tank after the fish had been subjected to a period of fasting of 48 hours to empty the gastrointestinal tract. After slaughter by thermal shock, the individual weights were taken for each fish, for the skin without scales, fillet without skin, heart, liver, gills and gastrointestinal tract.

Five mathematical models were evaluated in order to check those which would best describe the average growth curve for the characteristics of body weight, weight of fillet without skin, weight of skin without scales and weight of organs for GIFT strain Nile tilápia, when measured every two weeks,

1) Gompertz:

$Y=A e-e^{-K(t-C)}+\varepsilon$

where: $Y=$ weight $(\mathrm{g})$ of the animal at age $\mathrm{t} ; A=$ weight $(\mathrm{g})$ of the animal at maturity or asymptotic weight; $K=$ rate of maturity (per day); $C=$ time (days) of maximal growth 
Table 1 - Chemical composition of the commercial diets used in the experiment into the growth of GIFT strain Nile tilapia

\begin{tabular}{lccccc}
\hline \multirow{2}{*}{ Composition } & 45 & 40 & 35 & 32 & 28 \\
\cline { 2 - 5 } & 42.97 & 39.13 & 36.45 & 32.96 & 29.30 \\
\hline Protein (\%) & 10.18 & 3.05 & 2.32 & 2.43 & 2.08 \\
Lipids (\%) & 8.93 & 8.85 & 8.17 & 5.81 & 8.16 \\
Ash (\%) & 0.56 & 0.60 & 0.49 & 0.37 & 0.44 \\
Calcium (\%) & 0.96 & 0.85 & 0.81 & 0.76 & 0.92 \\
Magnesium (\%) & 4,570 & 4,129 & 4,079 & 4,124 & 4,012 \\
Brute Energy (cal g & (1) & & & & \\
\hline
\end{tabular}

rate, i.e. age at the inflection point; $t=$ time (age in days from birth); $e=$ natural logarithm base; and $\varepsilon=$ random error associated with each weight (FIALHO, 1999).

2) Logistic:

$Y=A\left(1+B e^{-K t}\right)^{-1}+\varepsilon$

where: $Y=$ weight $(\mathrm{g})$ of the animal at age $\mathrm{t} ; A=$ weight (g) of the animal at maturity or asymptotic weight; $B=$ constant of integration, related to the initial weight of the animal and with no well-defined biological interpretation; $K=$ rate of maturity (per day); $t=$ time (age in days from birth); $e=$ natural logarithm base; and $\varepsilon=$ random error associated with each weight (FREITAS, 2005).

3) Hyperbolic Linear:

$Y=B_{0}+B_{1} t+B_{2} t^{-1}+\varepsilon$

4) Quadratic:

$Y=B_{0}+B_{1} t+B_{2} t^{2}+\varepsilon$

5) Logarithmic Quadratic:

$Y=B_{0}+B_{1} t+B_{2} t^{2}+B_{3} I n t+\varepsilon$

where: $Y=$ weight $(\mathrm{g})$ of the animal at age $\mathrm{t} ; t=$ time (age in days from birth); $\mathrm{B}_{0}, \mathrm{~B}_{1}, \mathrm{~B}_{2}$ and $\mathrm{B}_{3}$ estimated regression coefficients; and $\varepsilon=$ random error associated with each weight (CRUZ; COSTA; RIBEIRO, 2009).

Parameters for the models were estimated by the modified Gauss Newton method, employing the NLIN procedure of the SAS software (1996). The criteria used to select the model that best described the growth curve were: residual mean square, adjusted coefficient of determination, residual mean absolute deviation and residual distribution chart.

With the model selected, the absolute rate of growth with respect to time $(\partial \mathrm{Y} / \partial \mathrm{t})$ was calculated, obtained from the first derivative of the adjusted model. According to studies by Sarmento et al. (2006), the absolute rate of growth is the gain in weight per unit of time. When time is expressed in days, this represents the average daily weight gain estimated for the growth trajectory, i.e. the average growth rate of the animals in the population.

\section{RESULTS AND DISCUSSION}

\section{Growth Curve for Body Weight}

The average water temperature was $27{ }^{\circ} \mathrm{C}$, dissolved oxygen $7.2 \mathrm{mg} \mathrm{L}^{-1}, \mathrm{pH} 6.8$, electrical conductivity $124 \mu \mathrm{S} \mathrm{cm}^{-1}$, total alkalinity $29 \mathrm{mg} \mathrm{L}^{-1}$, ammonia $58 \mu \mathrm{g} \mathrm{L}^{-1}$ and nitrite $28 \mu \mathrm{g} \mathrm{L}^{-1}$. Limnological parameters remained within the ideal range required by the fish, as recommended by Urbinati and Carneiro (2004).

The Gompertz model showed the highest adjusted coefficient of determination, while the Logistic, Quadratic and Logarithmic Quadratic models showed similar coefficients, and the Hyperbolic Linear model, the lowest (Table 2). This indicates that when adjusting the average curve, any of the models could be used.

The Gompertz and Logistic models showed the lowest values for residual mean square and mean absolute deviation, and were therefore the models that best fit the adjusted growth curve.

The smallest residuals were presented by the Gompertz and Logistic models, with larger fluctuations occurring between 115 and 160 days (Figure 1). For the mean curve, the Logistic model best represented the growth of the tilapia, since it showed lower residual dispersion as a function of time, indicating a good fit.

Among the linear models, the Quadratic and Logarithmic Quadratic were those that best fit the data set for weight as a function of time, since they showed the lowest values for residual mean square and mean absolute deviation, and higher values for adjusted 
Table 2 - Estimates of the parameters for body weight: residual mean square (RMS), adjusted coefficient of determination ( $\mathrm{R}_{\mathrm{a}}^{2}$ ) and mean absolute deviation (MAD), in accordance with the models studied for GIFT strain Nile tilapia

\begin{tabular}{|c|c|c|c|c|c|}
\hline \multirow[t]{2}{*}{ Model } & \multicolumn{2}{|c|}{ Estimate of Parameters } & \multirow[t]{2}{*}{ RMS } & \multirow[t]{2}{*}{$\mathrm{R}_{\mathrm{a}}^{2}$} & \multirow[t]{2}{*}{ MAD } \\
\hline & $\mathrm{A}$ & 763.6 & & & \\
\hline \multirow[t]{3}{*}{ Gompertz $^{1}$} & $\mathrm{~K}$ & 0.0159 & 244.2 & 0.988 & 4.21 \\
\hline & $\mathrm{C}$ & 186.6 & & & \\
\hline & $\mathrm{A}$ & 509.8 & & & \\
\hline \multirow[t]{3}{*}{ Logistic $^{1}$} & $\mathrm{~B}$ & 208.2 & 738.4 & 0.965 & 3.72 \\
\hline & $\mathrm{K}$ & 0.0381 & & & \\
\hline & $\mathrm{B}_{0}$ & -116.5 & & & \\
\hline \multirow[t]{3}{*}{ Hyperbolic Linear ${ }^{2}$} & $\mathrm{~B}_{1}$ & 2.6554 & 2673.3 & 0.874 & 24.23 \\
\hline & $\mathrm{B}_{2}$ & 121 & & & \\
\hline & $\mathrm{B}_{0}$ & 12.2174 & & & \\
\hline \multirow[t]{2}{*}{ Quadratic $^{2}$} & $\mathrm{~B}_{1}$ & -0.9404 & 828.3 & 0.961 & 7.08 \\
\hline & $\mathrm{B}_{2}$ & 0.0183 & & & \\
\hline \multirow{4}{*}{ Logarithmic Quadratic $^{2}$} & $\mathrm{~B}_{0}$ & 4.7525 & \multirow{4}{*}{821.5} & \multirow{4}{*}{0.961} & \multirow{4}{*}{6.22} \\
\hline & $\mathrm{B}_{1}$ & -1.3094 & & & \\
\hline & $\mathrm{B}_{2}$ & 0.0197 & & & \\
\hline & $\mathrm{B}_{3}$ & 6.3428 & & & \\
\hline
\end{tabular}

${ }^{1} \mathrm{~A}=$ weight at maturity, $\mathrm{B}=$ constant of integration, $\mathrm{K}=$ rate of maturing, $\mathrm{C}=$ time of maximal growth rate; ${ }^{2} \mathrm{~B}_{0} \cdot \mathrm{B}_{1}, \mathrm{~B}_{2}$ e $\mathrm{B}_{3}$ are estimated regression coefficients with no biological interpretation

Figure 1 - Observed and estimated growth curves and residual dispersion, in accordance with the Gompertz, Logistic, Hyperbolic Linear, Logarithmic Quadratic and Quadratic models for body weight in GIFT strain Nile tilapia

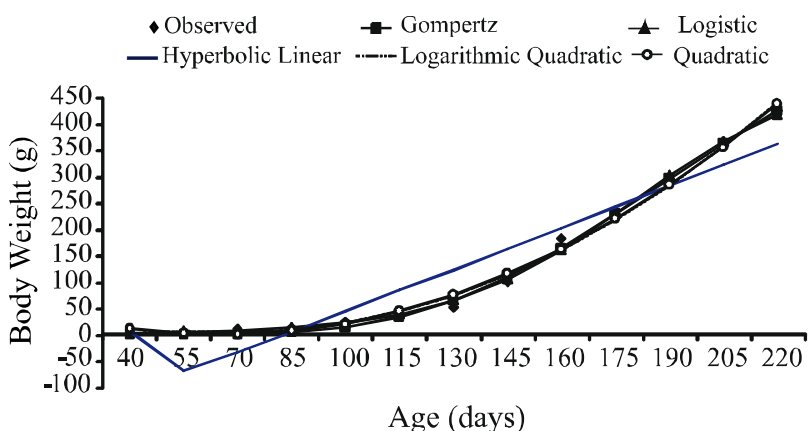

Age (days)

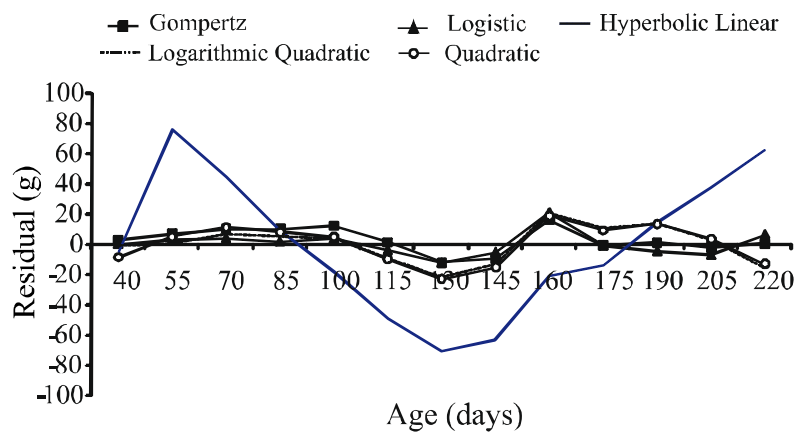

Bovenhuis and Komen (2004) found that GIFT strain Nile tilapia reached approximately $700 \mathrm{~g}$ after one year of breeding. It can therefore be inferred that the Gompertz model estimated the asymptotic weight to be near the adult weight of the GIFT strain, and that the Logistic model underestimated the asymptotic weight. A similar result was seen by Hernandez-Llamas and Ratkowsky (2004) and Katsanevakis and Maravelias (2008) when evaluating mathematical models to describe the growth of fish. 
As the Gompertz and Logistic models, in addition to adequately describing the average growth curve, can also be used to study components of the growth curve, the Gompertz function is recommended when describing the growth curve of GIFT strain Nile Tilapia, due to better having estimated the asymptotic weight.

For the Chitralada and Supreme strains, Santos et al. (2007) concluded that the Gompertz and von Bertalanffy models are more suitable in describing morphometric growth in the animals.

In the study carried out by Aguilar (2010) using the Chitralada strain of Nile tilapia, the asymptotic weight estimated by the Gompertz model was 719.45 , by the Logistic it was 614.13 , and by the von Bertalanffy, 820.44 . The author concluded that the von Bertalanffy model showed a better fit for the growth of body weight than the other models evaluated (Gompertz, Logistic, Janoschek, Michaelis-Menten and West). The Gompertz, Michaelis-Menten and West models however also presented a satisfactory fit.

Costa et al. (2009), employing the Brody, von Bertalanffy, Logistic, Gompertz and Exponential models to assess the growth of the Chitralada, GIFT, UFLA and Red strains of Nile tilapia, noted that the exponential model had the best fit for all strains.
This divergence between the works quoted demonstrates that there is need for further study in order to determine a more standardised methodology to describe the growth curves of fish bred in captivity, mainly with regard to the minimum number of animals sampled and the sampling interval, as these factors have an influence on the accuracy of the estimated values.

\section{Growth Curve for Fillet and Skin Weight}

The adjusted coefficient of determination for the Gompertz model was the highest, while the coefficients for the Logistic, Quadratic and Logarithmic Quadratic models were similar, and that of the Hyperbolic Linear model was the lowest (Tables 3 and 4).

Based on the values of the residual mean square, mean absolute deviation and residual distribution chart (Figures 2 and 3), the Gompertz and Logistic models presented the best fit to the growth curve of the fillet and skin, in the same way as happend with body weight.

Among the linear models, the Quadratic and Logarithmic Quadratic represented the growth curve well. Thus, to describe the average growth curve of fillet and skin, only the Hyperbolic Linear model should not be used.

Table 3 - Estimates of the parameters for fillet weight: residual mean square (RMS), adjusted coefficient of determination ( $\mathrm{R}_{\mathrm{a}}^{2}$ ) and mean absolute deviation (MAD), in accordance with the models studied for GIFT strain Nile tilapia

\begin{tabular}{|c|c|c|c|c|c|}
\hline \multirow[t]{2}{*}{ Model } & \multicolumn{2}{|c|}{ Estimate of Parameters } & \multirow[t]{2}{*}{ RMS } & \multirow[t]{2}{*}{$\mathrm{R}_{\mathrm{a}}^{2}$} & \multirow[t]{2}{*}{ MAD } \\
\hline & $\mathrm{A}$ & 235 & & & \\
\hline \multirow[t]{3}{*}{ Gompertz $^{1}$} & $\mathrm{~K}$ & 0.0190 & 39.9 & 0.986 & 1.66 \\
\hline & $\mathrm{C}$ & 177.2 & & & \\
\hline & A & 173.6 & & & \\
\hline \multirow[t]{3}{*}{ Logistic $^{1}$} & $\mathrm{~B}$ & 306.4 & 121.7 & 0.957 & 1.51 \\
\hline & $\mathrm{K}$ & 0.0417 & & & \\
\hline & $\mathrm{B}_{0}$ & -43.8389 & & & \\
\hline \multirow[t]{3}{*}{ Hyperbolic Linear $^{2}$} & $\mathrm{~B}_{1}$ & 0.9623 & 387.4 & 0.863 & 8.87 \\
\hline & $\mathrm{B}_{2}$ & 45.1029 & & & \\
\hline & $\mathrm{B}_{0}$ & 3.8509 & & & \\
\hline \multirow[t]{2}{*}{ Quadratic $^{2}$} & $\mathrm{~B}_{1}$ & -0.3674 & 137.3 & 0.951 & 2.88 \\
\hline & $\mathrm{B}_{2}$ & 0.00678 & & & \\
\hline \multirow{4}{*}{ Logarithmic Quadratic $^{2}$} & $\mathrm{~B}_{0}$ & 1.4232 & \multirow{4}{*}{136.8} & \multirow{4}{*}{0.952} & \multirow{4}{*}{2.60} \\
\hline & $\mathrm{B}_{1}$ & -0.4874 & & & \\
\hline & $\mathrm{B}_{2}$ & 0.00722 & & & \\
\hline & $\mathrm{B}_{3}$ & 2.0628 & & & \\
\hline
\end{tabular}

${ }^{1} \mathrm{~A}=$ weight at maturity $(\mathrm{g}), \mathrm{B}=$ constant of integration, $\mathrm{K}=$ rate of maturing, $\mathrm{C}=$ time of maximal growth rate, ${ }^{2} \mathrm{~B}_{0}, \mathrm{~B}_{1}, \mathrm{~B}_{2}$ e $\mathrm{B}_{3}$ are estimated regression coefficients with no biological interpretation 
Table 4 - Estimates of the parameters for skin weight: residual mean square (RMS), adjusted coefficient of determination (Ra2) and mean absolute deviation (MAD), in accordance with the models studied for GIFT strain Nile tilapia

\begin{tabular}{|c|c|c|c|c|c|}
\hline \multirow[t]{2}{*}{ Model } & \multicolumn{2}{|c|}{ Estimate of Parameters } & \multirow[t]{2}{*}{ RMS } & \multirow[t]{2}{*}{$\mathrm{R}_{\mathrm{a}}^{2}$} & \multirow[t]{2}{*}{ MAD } \\
\hline & $\mathrm{A}$ & 21.3225 & & & \\
\hline \multirow[t]{3}{*}{ Gompertz $^{1}$} & K & 0.0188 & \multirow[t]{3}{*}{0.46} & \multirow[t]{3}{*}{0.980} & \multirow[t]{3}{*}{0.18} \\
\hline & $\mathrm{C}$ & 179.5 & & & \\
\hline & A & 15.6338 & & & \\
\hline \multirow[t]{3}{*}{ Logistic $^{1}$} & B & 317.6 & \multirow[t]{3}{*}{1.20} & \multirow[t]{3}{*}{0.946} & \multirow[t]{3}{*}{0.18} \\
\hline & $\mathrm{K}$ & 0.0414 & & & \\
\hline & $\mathrm{B}_{0}$ & -3.9339 & & & \\
\hline \multirow[t]{3}{*}{ Hyperbolic Linear ${ }^{2}$} & $\mathrm{~B}_{1}$ & 0.0849 & \multirow[t]{3}{*}{3.39} & \multirow[t]{3}{*}{0.848} & \multirow[t]{3}{*}{0.81} \\
\hline & $\mathrm{B}_{2}$ & 4.0543 & & & \\
\hline & $\mathrm{B}_{0}$ & 0.4013 & & & \\
\hline \multirow[t]{3}{*}{ Quadratic $^{2}$} & $\mathrm{~B}_{1}$ & -0.0364 & \multirow[t]{3}{*}{1.28} & \multirow[t]{3}{*}{0.943} & \multirow[t]{3}{*}{0.27} \\
\hline & $\mathrm{B}_{2}$ & 0.000619 & & & \\
\hline & $\mathrm{B}_{0}$ & 0.1304 & & & \\
\hline \multirow{3}{*}{ Logarithmic Quadratic ${ }^{2}$} & $\mathrm{~B}_{1}$ & -0.0498 & \multirow{3}{*}{1.27} & \multirow{3}{*}{0.943} & \multirow{3}{*}{0.25} \\
\hline & $\mathrm{B}_{2}$ & 0.000668 & & & \\
\hline & $\mathrm{B}_{3}$ & 0.2302 & & & \\
\hline
\end{tabular}

${ }^{1} \mathrm{~A}=$ weight at maturity $(\mathrm{g}), \mathrm{B}=$ constant of integration, $\mathrm{K}=$ rate of maturing, $\mathrm{C}=$ time of maximal growth rate, ${ }^{2} \mathrm{~B}_{0}{ }^{\prime} \mathrm{B}_{1}, \mathrm{~B}_{2}$ e $\mathrm{B}_{3}$ are estimated regression coefficients with no biological interpretation

Figure 2 - Observed and estimated growth curves and residual dispersion, in accordance with the Gompertz, Logistic, Hyperbolic Linear, Logarithmic Quadratic and Quadratic models for fillet weight in GIFT strain Nile tilapia

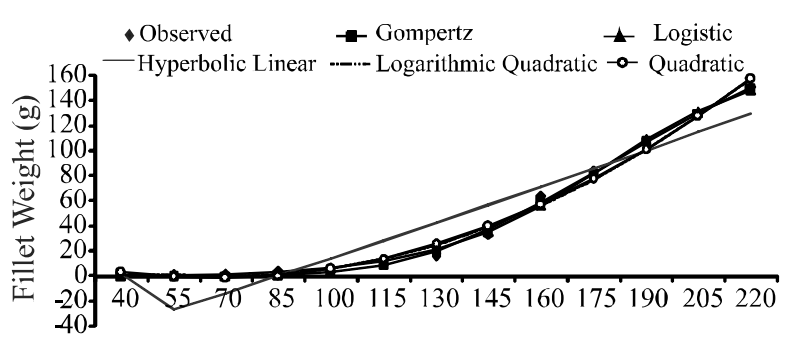

Age (days)

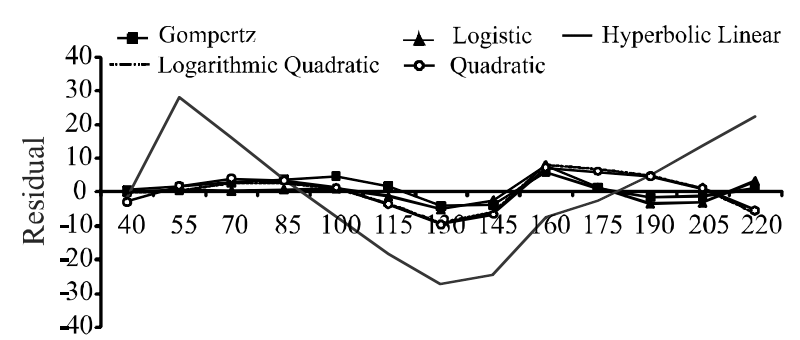

Age (days)

Figure 3 - Observed and estimated growth curves and residual dispersion, in accordance with the Gompertz, Logistic, Hyperbolic Linear, Logarithmic Quadratic and Quadratic models for skin weight in GIFT strain Nile tilapia

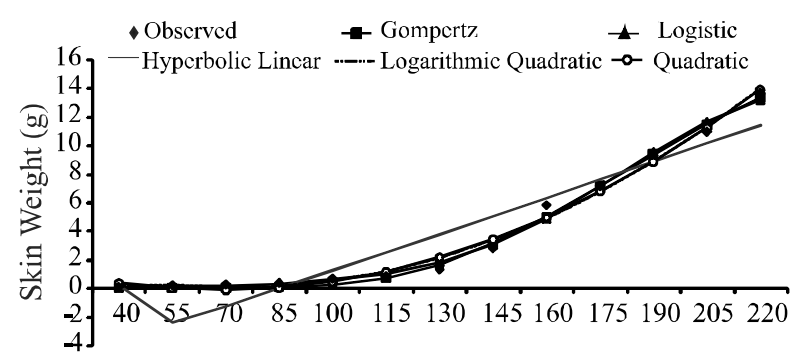

Age (days)

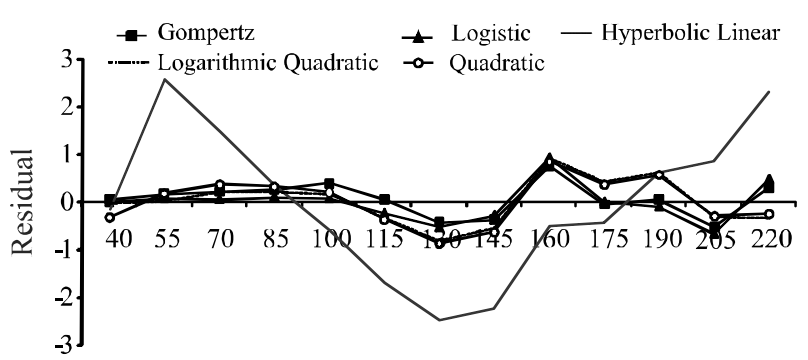

Age (days) 
The Gompertz model estimated the asymptotic weight of the fillet and skin to be 235 and $21.32 \mathrm{~g}$, and the Logistic to be 173.6 and $15.63 \mathrm{~g}$ respectively. According to data from the study by Pinheiro et al. (2006), specimens of Nile tilapia weighing between 600 and $800 \mathrm{~g}$ have an average yield of $31 \%$ fillet. Consequently, animals of $763.6 \mathrm{~g}$ have an approximate fillet weight of $236.71 \mathrm{~g}$. Souza et al. (2005) observed that specimens of tilapia with a weight of $731 \mathrm{~g}$ have skin weighing $24.43 \mathrm{~g}$.

Following the same trend as for body weight, the Gompertz model was superior to the Logistic model due to the estimated asymptotic weight, which was closer to the value observed for the species under practical conditions.

By the Gompertz model, asymptotic weight (A) was estimated to be 763.6, 235 and 21.3225; the rate of maturing $(\mathrm{K})$ to be 0.0159 . 0.0190 and 0.0188 ; and age at the point of inflection (C) to be 186.6, 177.2 and 179.2 days for the characteristics of body weight, fillet without skin and skin without scales respectively. It is seen that the values found for the rate of maturing were higher for fillet and skin weight and lower for body weight. The GIFT strain of Nile tilapia therefore reaches the age of maximum fillet and skin growth before that of body weight. This means that the growth rates between body parts are different, reflecting in differences in dietary requirements and therefore different feeding managements.

The earlier development of fillet and skin probably happened due to the proteinic tissue presenting an earlier deposition rate than the fatty tissue up until 220 days of age, reflecting that the breeding of GIFT strain tilapia possibly gave more priority to the early development of lean tissue.

\section{Growth Rates for the Characteristics of Body, Fillet and Skin Weight}

The growth rates $\left(\mathrm{GR}=\mathrm{A} \cdot \mathrm{K} \cdot \mathrm{e}-\mathrm{K}(\mathrm{t}-\mathrm{C})-\mathrm{e}^{-\mathrm{K}(\mathrm{t}-\mathrm{C})}\right)$ and the weights at the point of inflection $(\mathrm{PI}=\mathrm{A} / \mathrm{e})$ for the characteristics of body, fillet and skin weight were obtained by expressions derived from the Gompertz model (FIALHO, 1999), taking into account that this model was the most appropriate to represent the curve of body growth in GIFT strain Nile tilapia.

The highest growth rates were observed from 115 days, with the maximum growth rate for body weight being $4.47 \mathrm{~g} \mathrm{day}^{-1}$, for fillet $1.64 \mathrm{~g} \mathrm{day}^{-1}$ and for skin $0.15 \mathrm{~g} \mathrm{day}^{-1}$ (Figure 4). Weights at the point of inflection for body weight, fillet and skin were 280.92 , 86.45 and $7.84 \mathrm{~g}$ respectively.
It can be seen from the data that the maximum growth rates were achieved in the period near the age of sexual maturity, which, according to Li et al. (2006), occurs between 150 and 200 days of age and at a body weight exceeding $250 \mathrm{~g}$. Liu and Chang (1992) observed that the growth of Nile tilapia was affected by sexual maturity and that growth rates decreased after the start of reproduction.

In Chitralada strain Nile tilapia, Aguilar (2010) found that the rate of increase in body weight, as estimated by the von Bertalanffy model, was $3.295 \mathrm{~g}$ day $^{-1}$, age at the point of inflection was 176 days and weight at the point of inflection was $243 \mathrm{~g}$. Comparing these results with those obtained in the present study, it can be seen that the ages and weights at the point of inflection are close.

Figure 4 - Growth curves and growth rates (GR) for GIFT strain Nile tilapia, estimated by the Gompertz model, for the characteristics of body, fillet and skin weight. Where: $\mathrm{PI}=$ weight at the point of inflection; $\mathrm{C}=$ age at the point of inflection
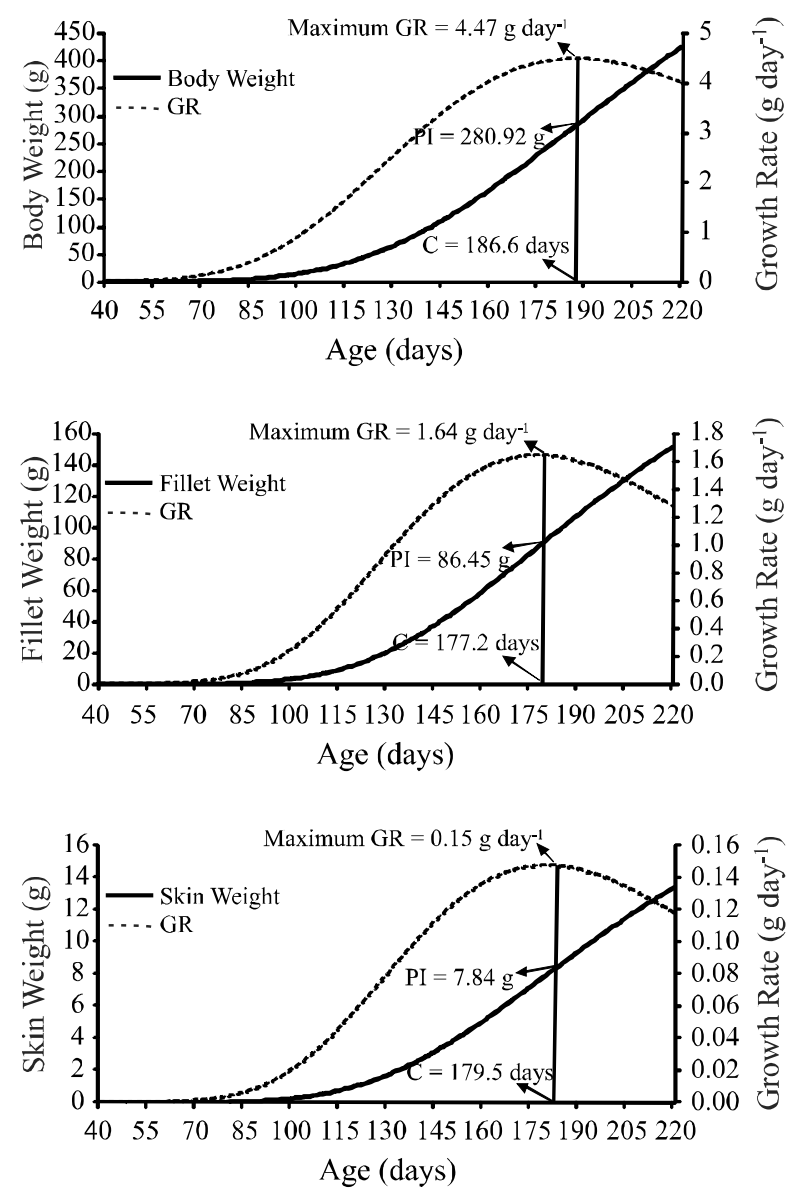


\section{Growth Curves and Growth Rates for the Organs}

The Gompertz model was used to describe the growth curves of the organs of GIFT strain Nile tilapia, by virtue of having presented the best fit to the data for body, fillet and skin weight.

As can be seen in Table 6, the values found for $\mathrm{K}$ were higher for the weight of the gills $(0.01850)$ and gastrointestinal tract $(0.01860)$, and lower for the weight of the heart (0.01240) and liver (0.00860). These results show that the age of maximum growth (C) of the heart and the liver was greater than that of the gills and gastrointestinal tract. Ages at the point of inflection for the gastrointestinal tract, gills, heart and liver weights were 151.5, 165.8, 203.4 and 274.3 days respectively.
Study of the growth of organs is important because it may lead to a better understanding of the physiology of the animals and the results of breeding. Rance, McEntee and McDevitt (2002) note that genetic selection has resulted in changes in organ size in broilers, including the heart, liver and gastrointestinal tract.

The maximum growth rate for the gastrointestinal tract was $0.111 \mathrm{~g} \mathrm{day}^{-1}, 0.107 \mathrm{~g} \mathrm{day}^{-1}$ for the gills, $0.005 \mathrm{~g} \mathrm{day}^{-1}$ for the heart and $0.118 \mathrm{~g} \mathrm{day}^{-1}$ for the liver (Figure 5). The weights at the point of inflection for the gastrointestinal tract, gills, heart and liver were $5.96,5.79,0.30$ and $13.71 \mathrm{~g}$ respectively.

The liver is considered to be the main metabolic organ of the body, so nutritional factors may interfere

Table 6 - Estimates from the Gompertz equation, of parameters for organ weights in GIFT strain Nile tilapia and adjusted coefficient of determination $\left(\mathrm{R}_{\mathrm{a}}{ }^{2}\right)$

\begin{tabular}{lcccc}
\hline \multirow{2}{*}{ Variable } & $\mathrm{A}$ & $\mathrm{K}$ & \multirow{2}{*}{$\mathrm{R}_{\mathrm{a}}{ }^{2}$} \\
\cline { 2 - 4 } & 1.0530 & 0.0124 & $\mathrm{C}$ & 0.947 \\
\hline Heart weight & 15.7491 & 0.0185 & 203.4 & 0.962 \\
Gills weight & 37.2649 & 0.0086 & 274.3 & 0.865 \\
Liver weight & 16.2151 & 0.0186 & 151.5 & 0.864 \\
Gastrointestinal tract weight & $16 .--{ }^{2}$ &
\end{tabular}

$\mathrm{A}=$ weight at maturity $(\mathrm{g}), \mathrm{K}=$ rate of maturing, $\mathrm{C}=$ time of maximal growth rate

Figure 5 - Growth curves and growth rates (GR) for GIFT strain Nile tilapia, estimated by the Gompertz model, for the characteristic of heart, gills, liver and gastrointestinal tract weights. Where: $\mathrm{PI}=$ weight at the point of inflection; $\mathrm{C}=$ age at the point of inflection
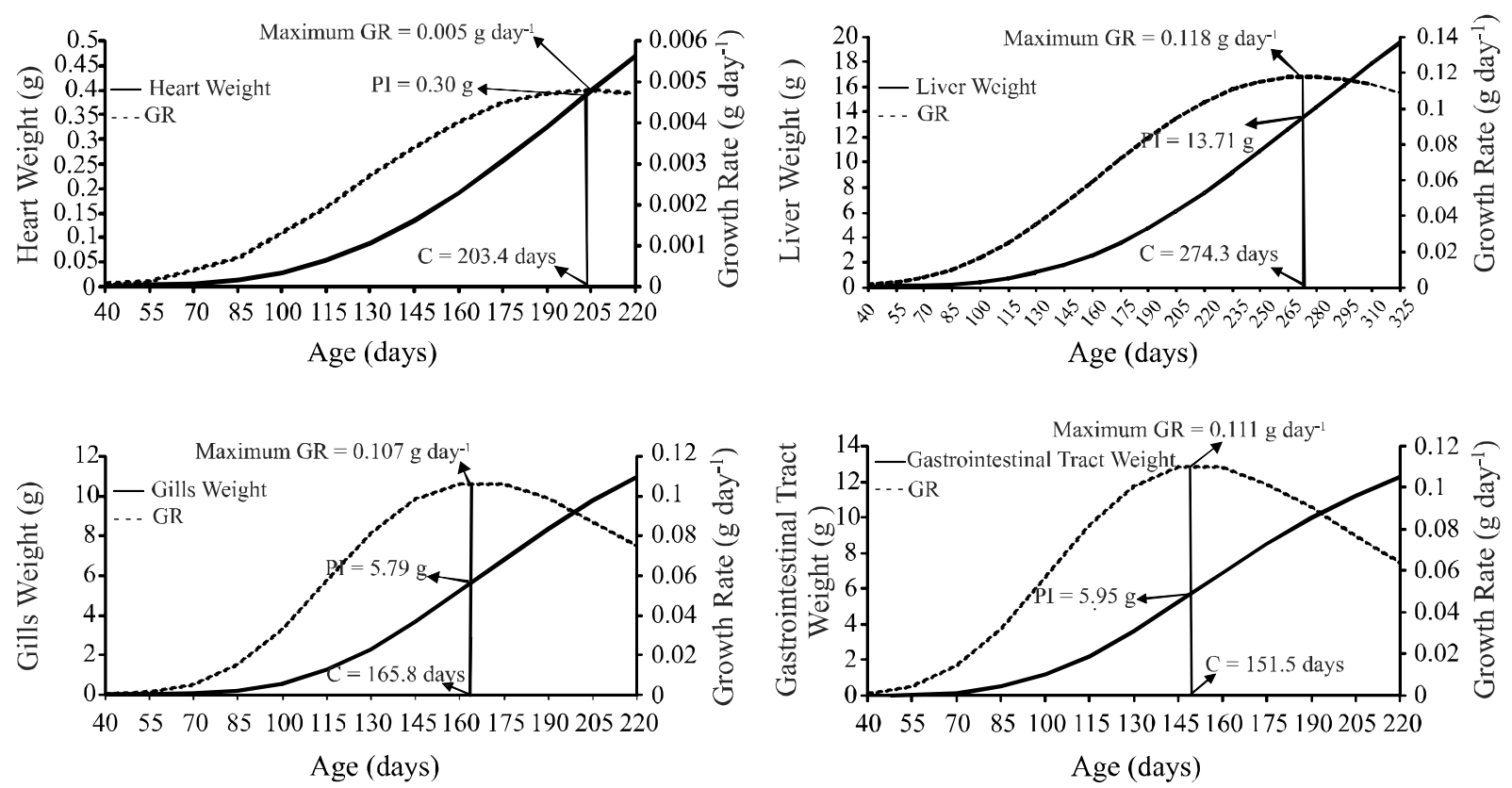
with its function. The organ participates in digestive functions through the synthesis and secretion of bile salts, and is also essential to the regulating of carbohydrates, proteins and lipids by the metabolism, to the storage of substances and the degradation and excretion of hormones (SCHINONI, 2006). In some fish, the liver, which can acquire considerable size, takes on an adipogenic role and is an organ for lipid reserves, in the same way as occurs in some birds (GUILLAUME et al., 2004).

\section{CONCLUSIONS}

1. Among the models evaluated, the Gompertz model is suggested for describing the body-growth curve of GIFT strain Nile tilapia, due to presenting the best fit for the data and more accurately estimating biological parameters and those of economic interest for this species, such as body weight and fillet weight;

2. The fillet and skin of GIFT strain Nile tilapia show earlier development than does body weight;

3. Among the organs studied, the age of maximum growth of the gastrointestinal tract and gills of GIFT strain Nile tilapia is less than that of the heart and the liver.

\section{ACKNOWLEDGEMENTS}

The authors wish to thank the National Council for Scientific and Tecnological Development (CNPq) for their financial support of this experiment, carried out at Julio de Mesquita Filho São Paulo State University, through the National Program for Academic Cooperation (PROCAD).

\section{REFERENCES}

AGUILAR, F. A. Modelos matemáticos no lineales como herramienta para evaluar el crecimiento de tilapia roja (Oreochromis spp.) y tilapia nilótica (Oreochromis niloticus Var. Chitralada)" alimentadas con dietas peletizadas o extruidas. 2010. 135 f. Dissertação (Mestrado em Produção Animal) - Faculdade de Medicina Veterinária e de Zootecnia, Universidade Nacional de Colômbia, Bogotá, 2010.

BIANCHINI SOBRINHO, E. Estudo da curva de lactação de vacas da raça Gir. 1984. 88 f. Tese (Doutorado em Genética). Universidade de São Paulo, Ribeirão Preto, 1984.

COSTA, A. C. et al. Avaliação do crescimento de tilápias de diferentes linhagens através de modelos não lineares. Archivos de Zootecnia, v. 58, p. 561-564, 2009. Suplemento 1.
CRUZ, G. R. B.; COSTA, R. G.; RIBEIRO, M. N. Curva de crescimento de caprinos mestiços no estado da Paraíba. Revista Brasileira de Ciências Agrárias, v. 4, n. 2, p. 204 210, 2009.

DAVE, B. K. Frist lactation curve of Indian water buffalo. Jawaharlal Nehru Krishi Vishwa Vidyalaya Research Journal, v. 5, n. 2, p. 93, 1971.

FIALHO, F. B. Interpretação da curva de crescimento de Gompertz. Embrapa Suínos e Aves, 1999. p. 1-4. (Comunicado Técnico, 237).

FREITAS A. R. Curvas de crescimento na produção animal. Revista Brasileira de Zootecnia, v. 34, n. 3, p. 786-795, 2005.

GOLTEMAN, H. L.; CLYMO, R. S.; OHNSTAD, M. A. M. Methods for physical and chemical analysis of freshwater. London: Blackwell Sci. Publ, 1978. 213 p.

GOUS, R. M. et al. Evaluation of the parameters needed to describe overall growth, the chemical growth and the growth of feathers and breast muscles of broiler. Poultry Science, v. 78, n. 6, p. 812-821, 1999.

GUILLAUME, J. et al. Nutrición y alimentación de peces y crustáceos. Madrid: Mundi-Prensa, 2004. 475 p.

GUPTA, M. V.; ACOSTA, B. O. From drawing board to dining table: The success story of the GIFT project. NAGA, WorldFish Center Quarterly, v. 27, n. 3/4, p. 4-14, 2004.

HERNANDEZ-LLAMAS, F.; RATKOWSKY, D. A. Growth of fishes, crustaceans and molluscs: estimation of the von Bertalanffy, Logistic, Gompertz and Richards curves and a new growth model. Marine Ecology Progress Series, v. 282, p. 237-244, 2004.

KATSANEVAKIS, S.; MARAVEliAS, C. D. Modelling fish growth: multi-model inference as a better alternative to a priori using von Bertalanffy equation. Fish and Fisheries, v. 9 , n. 2, p. 178-187, 2008.

LI, S.-F. et al. Improving growth performance and caudal fin stripe pattern in selected F6-F8 generations of GIFT Nile tilapia (Oreochromis niloticus L.) using mass selection. Aquaculture Research, v. 37, n. 12, p. 1165-1171, 2006.

LIU, K. M.; CHANG, W. Y. B. Bioenergetic modelling of effects of fertilization, stocking density, and spawning on growth of the Nile tiiapia, Oreochromis niloticus (L.). Aquaculture and Fisheries Management, v. 23, p. 291-301, 1992.

MARCATO, S. M. Características do Crescimento Corporal, dos Órgãos e Tecidos de Duas Linhagens Comerciais de Frangos de Corte. 2007. 183 f. Tese (Doutorado em Zootecnia) - Faculdade de Ciências Agrárias e Veterinárias, Universidade Estadual Paulista "Julio de Mesquita Filho", Jaboticabal, 2007.

PINHEIRO, L. M. S. et al. Rendimento industrial de filetagem da tilápia tailandesa (Oreochromis spp.). Arquivo Brasileiro de Medicina Veterinária e Zootecnia, v. 58, n. 2, p. 257-262, 2006. 
RANCE, K. A.; McENTEE, G. M.; McDEVITT, R. M. Genetic and phenotypic relationships between and within support and demand tissues in a single line of broiler chicken. British Poultry Science, v. 43, n. 4, p. 518-527, 2002.

RUTTEN, M. J. M.; BOVENHUIS, H.; KOMEN, H. Modeling fillet traits based on body measurements in three Nile tilapia strains (Oreochromis niloticus L.). Aquaculture, v. 231, n. 1/4, p. 113-122, 2004.

SANTOS, V. B. et al. Avaliação de curvas de crescimento morfométrico de linhagens de tilápia do Nilo (Oreochromis niloticus). Ciência e Agrotecnologia, v. 31, n. 5, p. 14861492, 2007.

SARMENTO, J. L. R. et al. Estudo da curva de crescimento de ovinos Santa Inês. Revista Brasileira de Zootecnia, v. 35, n. 2, p. 435-442, 2006.
SAS INSTITUTE. SAS/STAT User's guide. Version 6.12. Cary, North Caroline: SAS Institute Inc., 1996.

SCHINONI, M. I. Fisiologia Hepática. Gaz. Méd. Bahia, v. 76, p. 5-9, 2006. Suplemento 1

SOUZA, M. L. R. et al. Efeito do peso de tilápia do Nilo (Oreochromis niloticus) sobre o rendimento e a qualidade de seus filés defumados com e sem pele. Ciência e Tecnologia de Alimentos, v. 25, n. 1, p. 51-59, 2005.

THOLON, P.; QUEIROZ, S. A. Modelos matemáticos utilizados para descrever curvas de crescimento em aves aplicados ao melhoramento genético animal. Ciência Rural, v. 39, n. 7, p. 2261-2269, 2009.

URBINATI, E. C.; CARNEIRO, P. C. F. Práticas de manejo e estresse dos peixes em piscicultura. In: CYRINO, J. E. P. et al. Tópicos especiais em piscicultura de água doce tropical intensiva. São Paulo: TecArte, 2004. cap. 6, p. 171-193. 